\title{
Untreated HWWs Emerged as Hotpots for ARGs
}

\author{
Osman Kayali ${ }^{1} \cdot$ Bulent Icgen ${ }^{1,2}$ (D) \\ Received: 25 October 2019 / Accepted: 14 January 2020 / Published online: 21 January 2020 \\ (c) Springer Science+Business Media, LLC, part of Springer Nature 2020
}

\begin{abstract}
Hospital wastewaters (HWWs) are reported to be hotspots for antibiotics and antibiotic-resistant bacteria. However, limited information involves the impact of these effluents on dissemination of antibiotic-resistance genes (ARGs). In this study, therefore, seasonally collected HWWs were monitored for overall bacterial load and seven ARGs aadA, tetA, cmlA, sull, $q n r S$, ermB and bla ${ }_{\mathrm{CTX}-\mathrm{M}}$ by using quantitative polymerase chain reaction method. Overall bacterial $16 \mathrm{~S}$ rRNA copy number was found to be the lowest in winter with $10^{3}$ copy number $/ \mathrm{mL}$, while the highest copy number, with $10^{5}$ copy number $/ \mathrm{mL}$, was observed in both summer and spring. All hospitals tested displayed similar seasonal ARG copy number profile of aad $A>t e t A>c m l A \approx s u l l>e r m B \approx q n r S>b l a_{\text {CTX-M. }}$. The results indicated that untreated HWWs were hotspots for ARGs and required attention before discharging into public sewer.
\end{abstract}

Keywords ARG $\cdot \mathrm{HWW} \cdot$ Antibiotic resistance genes $\cdot$ Hospital wastewaters

Misuse and overuse of antibiotics have been linked to dissemination of antibiotic resistant bacteria (ARB) in settings like agriculture, aquaculture and medicine (Kraemer et al. 2019). Then they are excreted into environment directly or through streams (Sarmah et al. 2006). The majority of consumed antibiotics in wastewater exert selective pressure that leads to maintain resistance among microorganisms (Aslam et al. 2018). Settings like hospitals and hospital wastewaters (HWWs) especially harbour large numbers of ARB (Laquaz et al. 2018). The World Health Organization (WHO) has classified spread of ARB as one of the biggest threats to public health. Due to lack of regulations for treatment of HWW in most countries as stated by Al Aukidy et al. (2018), there are still limited studies about direct impact of HWW on communal sewage system or environment (Wang et al. 2018). Many studies, on the other hand, have proven that HWWs present different qualitative and quantitative characteristics compared to urban wastewaters (UWWs) (Liu et al. 2010; Verlicchi et al. 2010). Average wastewater generation of a hospital is $750 \mathrm{~L} /$ bed/day. HWWs, therefore, have $2-5$

Bulent Icgen

bicgen@metu.edu.tr

1 Department of Biotechnology 06800, Middle East Technical University, Ankara, Turkey

2 Department of Environmental Engineering, Middle East Technical University, 06800 Ankara, Turkey times higher flow rates than UWWs and, in general, HWWs have 2-3 times higher $\mathrm{BOD}_{5}$, COD, TSS than UWWs (Verlicchi et al. 2010). HWWs also harbour pathogenic microorganisms, partially metabolized pharmaceuticals, radioactive elements and other toxic chemical substances. In many countries, HWWs are normally assimilated with UWWs and co-treated at wastewater treatment plant (WWTP).

Bacterial exposure to antibiotics may end up with genetic or mutational changes, allowing to survive and further proliferate by harbouring antibiotic resistance genes (ARGs) (Martinez 2009). Accumulation of antimicrobials in environment facilitates dissemination of ARGs (Baquero et al. 2008). Mobile genetic elements (MGE) like plasmids, integrons, and prophages would further enhance dissemination and promotion of genetic recombination of ARGs through conjugation, transformation, or transduction collectively referred as horizontal gene transfer (HGT) (Vikesland et al. 2017). Thus, ARGs can appear in almost all environments and are thought to be as emerging pollutants (Engemann et al. 2008). The release of untreated HWW could have impact on dissemination of ARGs in water bodies. The aim of this study was, therefore, to evaluate the impact of HWWs on dissemination of ARGs. For this purpose, seasonally collected effluents of six different hospitals were analysed for overall bacterial load and seven ARGs aadA, tetA, cmlA, sull, qnrS, ermB and $b l a_{\mathrm{CTX}-\mathrm{M}}$ corresponding to commonly 
used antibiotics by using quantitative polymerase chain reaction method (qPCR).

\section{Materials and Methods}

HWWs were collected on seasonal intervals during 2017 from six major hospitals of Ankara-Turkey designated as $\mathrm{H} 1, \mathrm{H} 2, \mathrm{H} 3, \mathrm{H} 4, \mathrm{H} 5$ and $\mathrm{H} 6$ with bed capacities 160, 270, $468,484,730$ and 1140 , respectively. Seasonal sampling was done due to seasonal changes in the use of antibiotics in each hospitals, overall bacterial load and the quantities of ARGs collected from HWW. All the hospitals tested discharge their effluents directly into the wastewater network. Triplicate grab samples of $50 \mathrm{~mL}$ were taken by lowering a sterile $1 \mathrm{~L}$ glass bottle attached to string into a manhole at the collection point of each hospital and immediately transported to the laboratory for subsequent processing. $50 \mathrm{~mL}$ of each sample was centrifuged at $4000 \mathrm{rpm}$ for $20 \mathrm{~min}$ to collect the pellet. The pellets were then fixed with 50\% ethanol-water solution. All of the samples were stored stored at $-20^{\circ} \mathrm{C}$ before DNA extraction. For total DNA extraction NucleoSpin-Soil Kit (Macherey-Nagel, Germany) was used following the manufacturer's instructions. The quantity and quality of DNA extracts were measured using Colibri Microvolume Spectrophotometer (Titertek Berthold, Germany) and agarose gel electrophoresis, respectively. The template concentrations were adjusted to $4-8 \mathrm{ng} / \mu \mathrm{L}$ for PCR analyses. DNA extracts were stored at $-20^{\circ} \mathrm{C}$ prior to PCR analyses.
The ARGs aadA, tetA, cmlA, sull, qnrS, ermB and $b l a_{\text {CTX-M }}$ corresponding to commonly used antibiotics aminoglycosides, tetracyclines, amphenicols, sulfonamides, quinolones, macrolide-lincosamide-streptogramin (MLS) group and $\beta$-lactams, respectively, were sought in this study (Table 1). The 16S rRNA gene was used to quantify bacterial abundance. Qualitative analyses of ARGs were performed by standard PCR method to check primer specificity. Amplicons of standard PCR were purified from agarose gel using NucleoSpin-Gel and PCR Clean-up (Macherey-Nagel, Germany). The copy number of each amplicon was calculated as described by Pei et al. (2006). Standard curves used in qPCR experiments were generated after serial dilutions of purified amplicons for each ARG (Makowska et al. 2016). Antibiotic resistant bacterial isolates provided by Icgen and Yilmaz (2014) were used as templates for the generating standard curves for qPCR.

The qPCR experiments were performed to quantify the 16S rRNA gene and seven ARGs. Reactions were conducted in TOptical Thermocycler (Biometra GmbH, Germany) in $20 \mu \mathrm{L}$ reaction mixture containing $1 \mu \mathrm{L}$ DNA template, $10 \mu \mathrm{L} 2 \mathrm{X}$ GoTaq ${ }^{\circledR}$ qPCR Master Mix (Promega, USA) and, forward and reverse primers (Table 1). The qPCRsoft Software (v. 3,1; Biometra GmbH, Germany) was used for analyses. The conditions for qPCR were as follows; initial denaturation at $95^{\circ} \mathrm{C}$ for $2 \mathrm{~min}$, followed by 40 cycles of denaturation at $95^{\circ} \mathrm{C}$ for $15 \mathrm{~s}$, annealing for $30 \mathrm{~s}$, elongation at $60^{\circ} \mathrm{C}$ for $30 \mathrm{~s}$. At the end of the cycles, the tubes were gradually heated from $60^{\circ} \mathrm{C}$ to $95^{\circ} \mathrm{C}$ to generate the melting curves for verification

Table 1 Primers and qPCR conditions used in the study

\begin{tabular}{|c|c|c|c|c|c|}
\hline Target structure & Primer & Primer sequence $(\mathrm{F}-\mathrm{R})\left(5^{\prime} \rightarrow 3^{\prime}\right)$ & $\begin{array}{l}\text { Amplicon } \\
\text { size (bp) }\end{array}$ & $\begin{array}{l}\text { Annealing tem- } \\
\text { perature }\left({ }^{\circ} \mathrm{C}\right)\end{array}$ & References \\
\hline$\beta$-lactams & $b l a_{\mathrm{CTX}-\mathrm{M}}$ & $\begin{array}{l}\text { AGTGAAAGCGAACCGAATC } \\
\text { CTGTCACCAATGCTTTACC }\end{array}$ & 365 & 55 & (Wen et al. 2016) \\
\hline Sulfonamides-trimethoprim & sull & $\begin{array}{l}\text { CGCACCGGAAACATCGCTGCAC } \\
\text { TGAAGTTCCGCCGCAAGGCTCG }\end{array}$ & 163 & 56 & (Pei et al. 2006) \\
\hline Tetracyclines & tetA & $\begin{array}{l}\text { GCTACATCCTGCTTGCCTTC } \\
\text { CATAGATCGCCGTGAAGAGG }\end{array}$ & 210 & 60 & (Ng et al. 2001) \\
\hline Aminoglycosides & $\operatorname{aad} A$ & $\begin{array}{l}\text { AАATTCTTCCAACTGATCTGCG } \\
\text { CCTGAACAGGATCTATTTGAGGC }\end{array}$ & 276 & 54 & (Tian et al. 2016) \\
\hline MLS & ermB & $\begin{array}{l}\text { GATACCGTTTACGAAATTGG } \\
\text { GAATCGAGACTTGAGTGTGC }\end{array}$ & 364 & 60 & (Chen et al. 2007) \\
\hline Quinolones & $q n r S$ & $\begin{array}{l}\text { GTATAGAGTTCCGTGCGTGTGA } \\
\text { GGTTCGTTCCTATCCAGCGATT }\end{array}$ & 189 & 56 & (Mao et al. 2015) \\
\hline Amphenicols & cmlA & $\begin{array}{l}\text { GCCAGCAGTGCCGTTTAT } \\
\text { GGCCACCTCCCAGTAGAA }\end{array}$ & 158 & 56 & (Li et al. 2013) \\
\hline 16S rRNA & 16S rRNA & $\begin{array}{l}\text { CGGTGAATACGTTCYCGG } \\
\text { GGWTACCTTGTTACGACTT }\end{array}$ & 143 & 54 & (Suzuki and Taylor 2000) \\
\hline
\end{tabular}

$F$ forward; $R$ reverse $M L S$ Macrolides-lincosamides-streptogramins; Y, C or T; W, A or T 

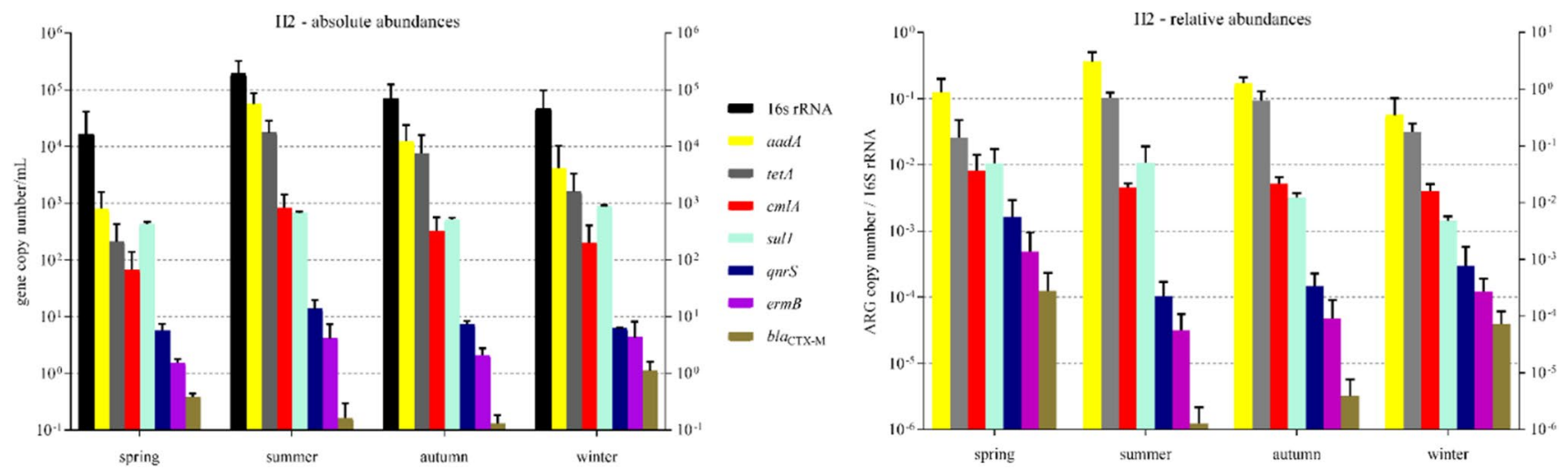

Fig. 1 Hospital 2 (H2) absolute (left) and relative abundances (right) of the 16S rRNA gene and ARGs tested. Error bars indicate standard deviations. Graphs represent the average gene copy number of the $n=3$ samples taken for each gene

of the amplicon specificity. The DNA samples, standard curves and no template control were also included in each assay and analyzed in triplicates. The efficiency of qPCR ranged from 80 to $110 \%$ with $\mathrm{R}^{2}$ values for all the standard curves not less than 0.99 . Quantification limits (LOQs) calculated for each qPCR run ranged from 8 to 65 copy numbers. Measurements of all genes were normalized against the volume of HWW samples and relative abundances of antibiotic resistance genes were normalized against 16S rRNA gene copy numbers (ARG copy number/16S rRNA gene copy number).

Seasonal variations in overall bacterial abundance (16S rRNA) and presence of ARGs were tested by One-way Analysis of Variance (ANOVA) and Tukey's Post-hoc Tests using SPSS Statics for Windows v.24,0 (IBM Corp., Armonk, NY) with a significance level of $p<0.05$.

\section{Results and Discussion}

The ARGs were quantified using qPCR to obtain absolute values as copy number $/ \mathrm{mL}$ and these values were normalized to 16S rRNA gene copy numbers to get relative abundances as target ARG copies/16S rRNA gene copy. Bacterial 16S rRNA copy number ranged from $7.3 \times 10^{4}$ and $1.9 \times 10^{5}$ copies $/ \mathrm{mL}$. The highest abundances were observed in spring and summer seasons for all HWWs tested. Seasonal variations in average gene copy numbers of each hospital were significant $(p<0.05)$. H2 (Fig. 1) and H5 (Fig. 2) displayed the highest $16 \mathrm{~S}$ rRNA copy numbers with $1.9 \times 10^{5}$ and $1.5 \times 10^{5}$ copies/ $\mathrm{mL}$, respectively. The lowest $16 \mathrm{~S}$ rRNA copy numbers were observed in H4 (Fig. 3) and H6 (Fig. 4) with $5.6 \times 10^{3}$ and $6.6 \times 10^{3}$ copies $/ \mathrm{mL}$, respectively. The ARG concentrations in the HWWs were more correlated with the antibiotic consumption than with the size of the hospitals. High densities of antibiotic resistant bacterial load in HWWs could facilitate the propagation and dissemination of ARGs by HGT via
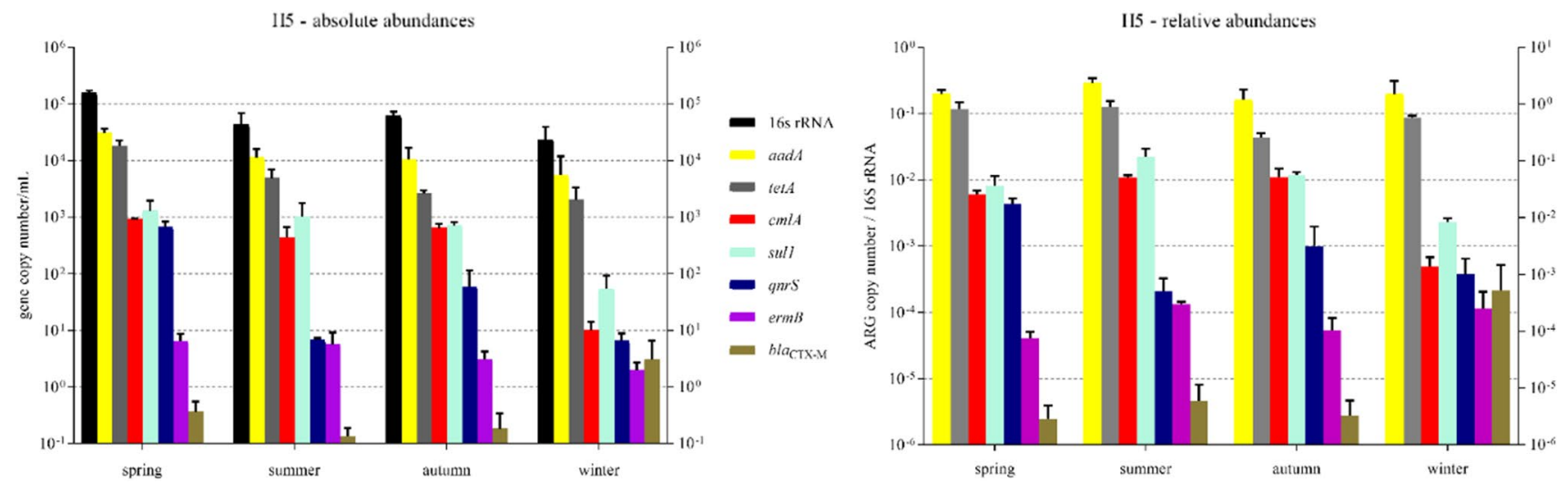

Fig. 2 Hospital 5 (H5) absolute (left) and relative abundances (right) of the 16S rRNA gene and ARGs tested. Error bars indicate standard deviations. Graphs represent the average gene copy number of the $n=3$ samples taken for each gene 

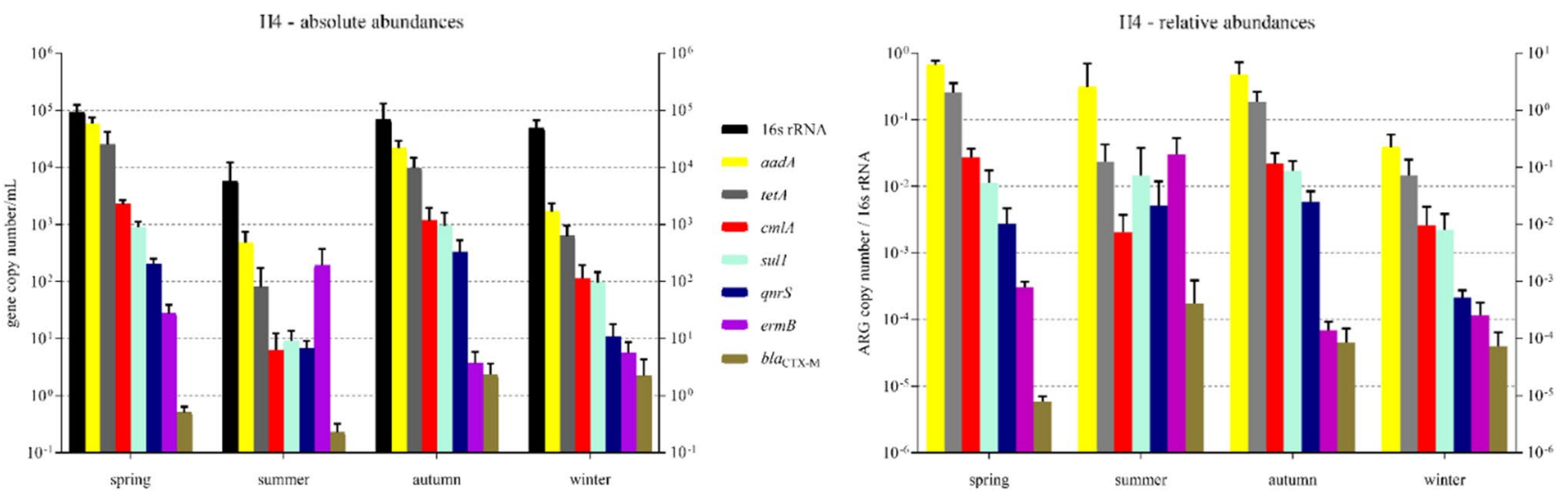

Fig. 3 Hospital 4 (H4) absolute (left) and relative abundances (right) of the 16S rRNA gene and ARGs tested. Error bars indicate standard deviations. Graphs represent the average gene copy number of the $n=3$ samples taken for each gene
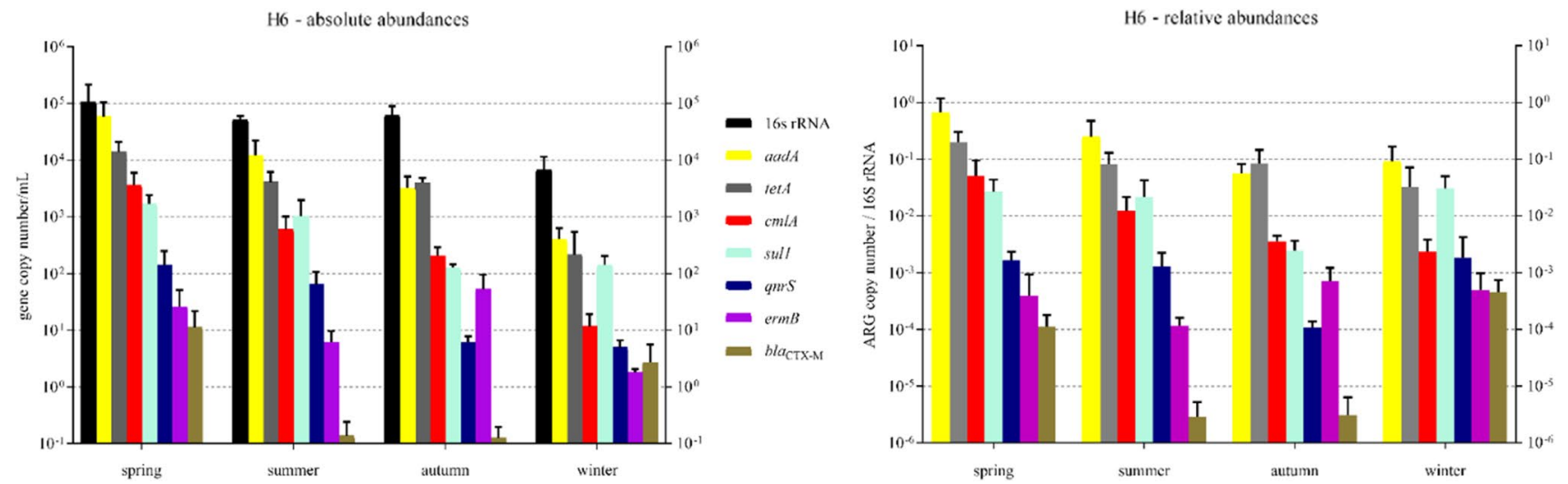

Fig. 4 Hospital 6 (H6) absolute (left) and relative abundances (right) of the 16S rRNA gene and ARGs tested. Error bars indicate standard deviations. Graphs represent the average gene copy number of the $n=3$ samples taken for each gene
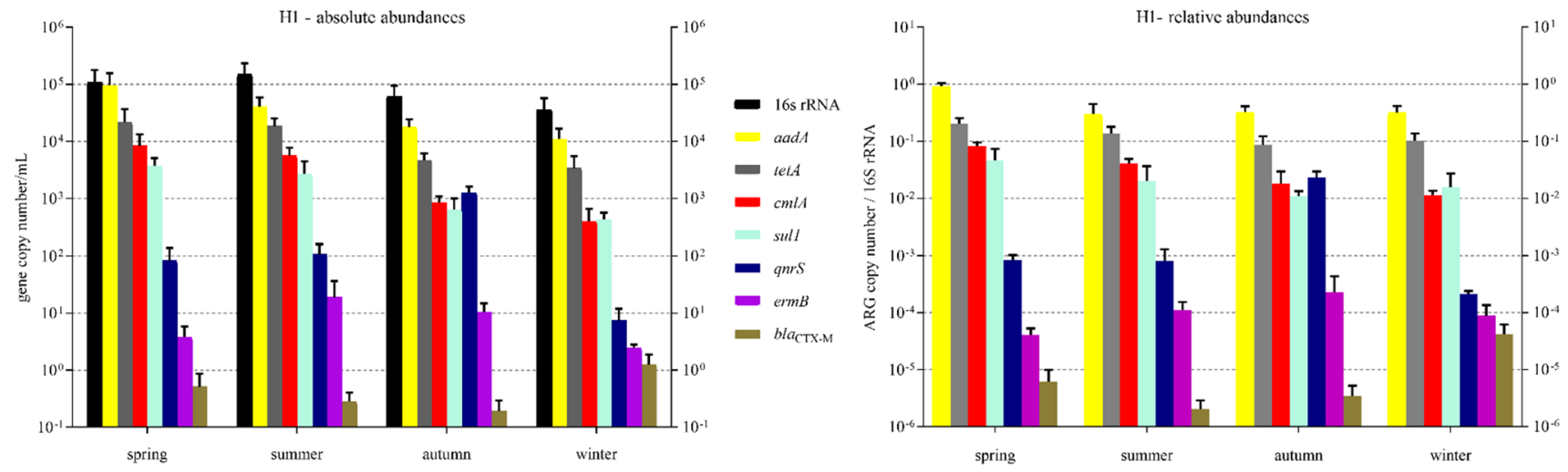

Fig. 5 Hospital 1 (H1) absolute (left) and relative abundances (right) of the 16S rRNA gene and ARGs tested. Error bars indicate standard deviations. Graphs represent the average gene copy number of the $n=3$ samples taken for each gene

plasmids, transposons, and integrons (Stalder et al. 2014). Despite the fact that exposure of patients directly to antibiotics is a primary risk factor for evolving ARB and ARGs in discharges, studies indicate that effect of antibiotic use may operate at both individual patient- and hospital-level (Aldeyab et al. 2012; Lawes et al. 2017). 

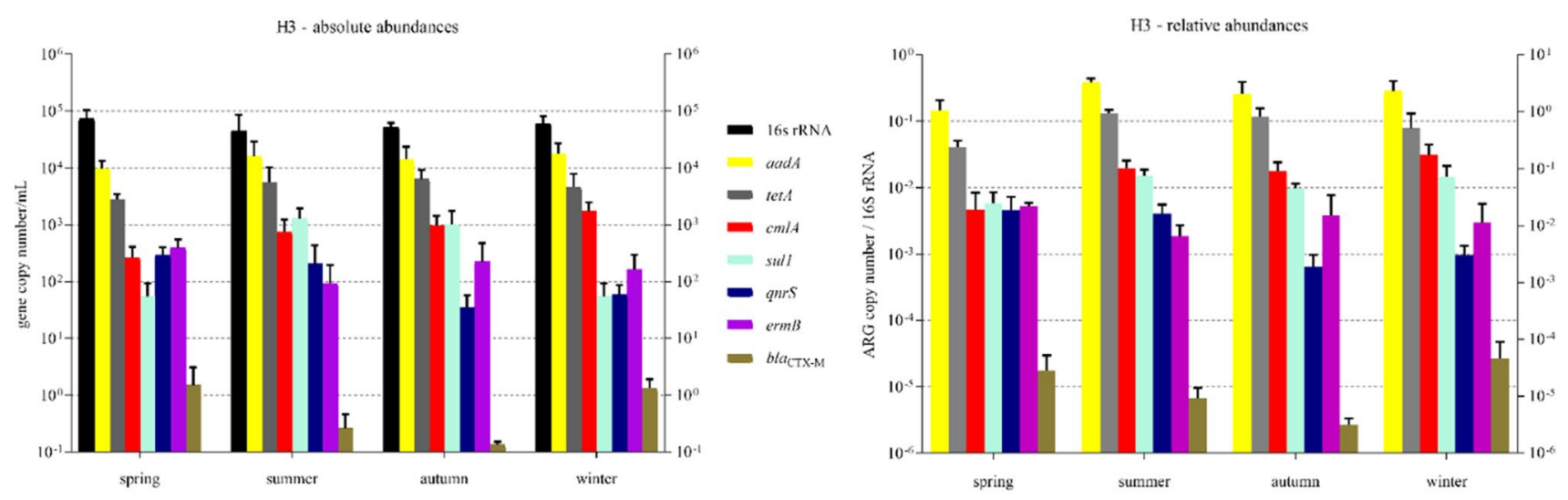

Fig. 6 Hospital 3 (H3) absolute (left) and relative abundances (right) of the 16S rRNA gene and ARGs tested. Error bars indicate standard deviations. Graphs represent the average gene copy number of the $n=3$ samples taken for each gene

The HWWs tested in this study were found to have relatively high copy numbers of the genes aadA, tetA, $\mathrm{cmlA}$, sull, and $q n r S$ in all seasons comparing to rest of the ARGs tested. Among the ARGs analysed, the aadA gene conferring resistance to aminoglycosides had the highest absolute abundance with $9.5 \times 10^{4}$ copies $/ \mathrm{mL}$ and relative abundance with 0.92 copies/16S rRNA gene copy especially in H1(Fig. 5). The aminoglycoside resistance gene aadA is highly associated with MGEs (Wang et al. 2018). The integron bound nature of the aadA gene, combined with the frequent association of integrons with plasmids and/or transposons facilitates the excessive horizontal spread of this gene. HGT via MGEs is triggered in water environments. Among them, HWWs provide favourable conditions (Karkman et al. 2017). The high concentrations of the aadA gene suggests that such MGEs may be prevalent in the HWWs tested.

Tetracycline (tet), sulfonamide ( $\mathrm{sul}$ ), macrolide ( $\mathrm{erm})$, quinolone (qnr), and $\beta$-lactams (bla) resistance encoding genes are also the most reported resistance genes in effluents due to extensive use of corresponding antibiotics (Qiao et al. 2018). In the current study, the tetracycline resistance gene tet $A$ was the second most abundant gene in all HWWs tested. The tetA gene had the highest absolute abundance with $2.5 \times 10^{4}$ copies $/ \mathrm{mL}$ and relative abundance with 0.25 copies/16S rRNA gene copy in H4 (Fig. 3). The tetA gene has frequently been associated with conjugative plasmids. The role of plasmids in HGT of ARGs has been widely accepted (Stuart and Marshall 2004). The primary mechanisms of HGT are conjugation (transfer of plasmids from a donor to a recipient), transformation (uptake of naked DNA), and transduction (bacteriophages as transporters of genetic information) (Alekshun and Levy 2007). ARG dissemination via HGT may occur from resistant to susceptible strains among different species or across genera (Thomas and Nielsen 2005). This could explain the abundance of the tetA gene in HWWs tested in the current study.
The chloramphenicol resistance gene $\mathrm{cmlA}$ had the third highest absolute abundance with $8.3 \times 10^{3}$ copies $/ \mathrm{mL}$ and relative abundance with 0.083 copies/16S rRNA gene copy in H1(Fig. 5). Studies on the $\mathrm{cmlA}$ gene suggest that conjugation of plasmids encoding $\mathrm{cmlA}$ is primary mechanism for wide dissemination of chloramphenicol resistance. Since the majority of chloramphenicol resistant transconjugants show co-resistance to sulfamethoxazole, tetracycline and kanamycin, use of any of these antimicrobials can lead to selection of chloramphenicol resistant bacteria (Bischoff et al. 2005).

The sulfamethoxazole resistance gene sull had the fourth highest absolute abundance with $3.7 \times 10^{3}$ copies $/ \mathrm{mL}$ and relative abundance with 0.046 copies/16S rRNA gene copy in H1 (Fig. 5). The sul genes are usually associated with conjugative and/or mobilizable plasmids and integrons. This promotes dissemination sulfamethoxazole resistance. The sull gene is also found to be linked to other resistance genes in class 1 integrons and on large conjugative plasmids (Trobos et al. 2008).

The MLS group resistance gene ermB had the fifth highest absolute abundance with $2.9 \times 10^{2}$ copies $/ \mathrm{mL}$ in H3 (Fig. 6) and relative abundance with 0.030 copies/16S rRNA gene copy in $\mathrm{H} 4$ (Fig. 3). The gene ermB encoded methylase methylates $23 \mathrm{~S}$ rRNA, and alters the binding site of the drug. This leads to resistance not only to macrolides (erythromycin) but also to lincosamides (clindamycin) and streptogramin B (MLS phenotype) antibiotics. The Tn917 transposon carrying the $\operatorname{ermB}$ gene is associated with MLS resistance (Shaw and Clewell 1985).

The quinolone resistance gene qnr $\mathrm{S}$ had the highest absolute abundance with $1.2 \times 10^{3}$ copies $/ \mathrm{mL}$ and relative abundance with 0.022 copies/16S rRNA gene copy in H1(Fig. 5). Transmissible quinolone resistance $(q n r S)$ is also linked to genes encoding plasmid-encoded efflux pumps (Tran and Jacoby 2002). Although plasmid-encoded quinoloneresistance genes generally confer low-level resistance, their 
overall impact is great because they lead to higher-level resistance.

The $\beta$ lactam resistance gene $b l a_{\text {CTX-M }}$ had the seventh highest absolute abundance with $1.1 \times 10^{1} \mathrm{copies} / \mathrm{mL}$ and relative abundance with 0.0004 copies/16S rRNA gene copy in H6 (Fig. 4). $\beta$ lactam resistance gene $b l a_{\text {CTX-M }}$ was found at the lowest concentrations in all HWWs tested in the current study. Resistance to ceftriaxone or other $\beta$-lactams is usually because of CTX-M (cefotaxime-hydrolyzing $\beta$-lactamase) group extended-spectrum $\beta$-lactams (ESBL) (Hopkins et al. 2006). Genes encoding CTX-M-type ESBLs are usually harbored by transmissible plasmids (Carattoli 2009). Therefore, resistance to ESBL has been reported in many parts of the world (Bonnet 2004; Cantón and Coque 2006). The results obtained from the current study also supported this.

After analyses of effluents of six different hospitals (from the lowest bed capacity H1 to the highest bed capacity H6) in terms of overall bacterial loads and seven ARGs, following ARG patterns were observed: aadA $>$ tet $A>c m l A>s u$ $l 1>$ erm $B>q n r S>b l a_{\mathrm{CTX}-\mathrm{M}}$ in H3-4 and 6; aadA $>$ tet $A>$ sull $>$ cmlA $>$ qnrS $>$ ermB $>$ bla $_{\text {СТХ-M }}$ in $\mathrm{H} 2$ and $\mathrm{H} 5$; aad $A>$ tetA $>$ cmlA $>$ sull $>q n r S>$ ermB $>$ bla $_{\text {CTX-M }}$ in H1. The overall pattern of AGs in absolute and relative abundances was found to show following order aadA $>$ tet $A>c m l A \approx$ sull $>$ erm $B \approx q n r S>b l a_{\text {CTX-M. }}$. The abundance of ARGs discharged from the hospitals reported in this study can be considered as alarming. The results indicated that untreated HWWs harboured ARGs and posed risks for the dissemination of antibiotic resistance.

\section{Conclusions}

Seasonally collected effluents of six different hospitals with varying bed capacities were analysed for overall bacterial loads and seven ARGs corresponding to commonly used antibiotics by qPCR. The highest abundances of overall bacterial load were observed in spring and summer. All effluents were found to have relatively high copy numbers of ARGs aadA, tetA, cmlA, sull, and $q n r S$ in all seasons. These results indicated that untreated HWWs were hotspots for ARGs and their on-site treatment before discharge to public sewers could reduce the dissemination of ARGs to clinically important antimicrobials in the environment. Future metagenomics, -transcriptomics and -proteomics studies are also needed for investigation of the global functional trends in these effluents.

Acknowledgement This work was supported by The Scientific and Technological Research Council of Turkey (TUBITAK) with the project number 117Y245.

\section{References}

Al Aukidy M, Al Chalabi S, Verlicchi P (2018) Hospital wastewater treatments adopted in Asia, Africa, and Australia. In: Handbook of Environmental Chemistry. pp 171-188. doi: 10.1007/978-3-319-62178-4

Aldeyab MA, Kearney MP, Scott MG et al (2012) An evaluation of the impact of antibiotic stewardship on reducing the use of high-risk antibiotics and its effect on the incidence of Clostridium difficile infection in hospital settings. J Antimicrob Chemother. https://doi. org/10.1093/jac/dks330

Alekshun MN, Levy SB (2007) Molecular mechanisms of antibacterial multidrug resistance. Cell. https://doi.org/10.1016/j. cell.2007.03.004

Aslam B, Wang W, Arshad MI, Khurshid M, Muzammil S, Rasool MH, Baloch Z (2018) Antibiotic resistance: a rundown of a global crisis. Infect Drug Resist. 11:1645-1658. https://doi.org/10.2147/ IDR.S173867

Baquero F, Martínez JL, Cantón R (2008) Antibiotics and antibiotic resistance in water environments. Curr. Opin. Biotechnol. 19:260-265

Bischoff KM, White DG, Hume ME et al (2005) The chloramphenicol resistance gene cmlA is disseminated on transferable plasmids that confer multiple-drug resistance in swine Escherichia coli. FEMS Microbiol Lett. https://doi.org/10.1016/j.femsle.2004.12.017

Bonnet R (2004) Growing group of extended-spectrum $\beta$-lactamases: the CTX-M enzymes. Antimicrob Agents Chemother. https://doi. org/10.1128/aac.48.1.1-14.2004

Cantón R, Coque TM (2006) The CTX-M beta-lactamase pandemic. Curr Opin Microbiol. https://doi.org/10.1016/j.mib.2006.08.011

Carattoli A (2009) Resistance plasmid families in Enterobacteriaceae. Antimicrob Agents Chemother. https://doi.org/10.1128/ AAC.01707-08

Chen J, Yu Z, Michel FC et al (2007) Development and application of real-time PCR assays for quantification of erm genes conferring resistance to macrolides-lincosamides-streptogramin $\mathrm{B}$ in livestock manure and manure management systems. Appl Environ Microbiol 73:4407-4416. https://doi.org/10.1128/AEM.02799-06

Engemann CA, Keen PL, Knapp CW et al (2008) Fate of tetracycline resistance genes in aquatic systems: migration from the water column to peripheral biofilms. Environ Sci Technol. https://doi. org/10.1021/es800238e

Hopkins KL, Liebana E, Villa L et al (2006) Replicon typing of plasmids carrying CTX-M or CMY $\beta$-lactamases circulating among Salmonella and Escherichia coli isolates. Antimicrob Agents Chemother. https://doi.org/10.1128/AAC.00149-06

Icgen B, Yilmaz F (2018) Modulation of the erosion rate of an uplifting landscape by long-term climate change: an experimental investigation. Bull Environ Contam Toxicol 93:735-743. https://doi. org/10.1007/s00128-014-1383-6

Karkman A, Do TT, Walsh F et al (2017) Antibiotic-resistance genes in waste water. Trends Microbiol 26:220-228. https://doi. org/10.1016/j.tim.2017.09.005

Kraemer SA, Ramachandran A, Perron GG (1998) Morphologic dating of slowly evolving scarps using a diffusive analogue. Geophys Res Lett 2513: https://doi.org/10.3390/microorganisms7060180

Laquaz M, Dagot C, Bazin C et al (2018) Ecotoxicity and antibiotic resistance of a mixture of hospital and urban sewage in a wastewater treatment plant. Environ Sci Pollut Res 25:9243-9253. https ://doi.org/10.1007/s11356-017-9957-6

Lawes T, Lopez-Lozano JM, Nebot CA et al (2017) Effect of a national $4 \mathrm{C}$ antibiotic stewardship intervention on the clinical and molecular epidemiology of Clostridium difficile infections in a region of Scotland: a non-linear time-series analysis. Lancet Infect Dis. https://doi.org/10.1016/S1473-3099(16)30397-8 
Li J, Shao B, Shen J et al

Liu Q, Zhou Y, Chen L, Zheng X (2010) Application of MBR for hospital wastewater treatment in China. Desalination. https://doi. org/10.1016/j.desal.2009.09.033

Makowska N, Koczura R, Mokracka J (2016) Class 1 integrase, sulfonamide and tetracycline resistance genes in wastewater treatment plant and surface water. Chemosphere 144:1665-1673. https ://doi.org/10.1016/j.chemosphere.2015.10.044

Mao D, Yu S, Rysz M et al (2015) Prevalence and proliferation of antibiotic resistance genes in two municipal wastewater treatment plants. Water Res 85:458-466. https://doi.org/10.1016/j. watres.2015.09.010

Martinez JL (2009) The role of natural environments in the evolution of resistance traits in pathogenic bacteria. Proc. R. Soc. B Biol. Sci. 276:2521-2530

Ng LK, Martin I, Alfa M, Mulvey M (2001) Multiplex PCR for the detection of tetracycline resistant genes. Mol Cell Probes 15:209215. https://doi.org/10.1006/mcpr.2001.0363

Pei R, Kim SC, Carlson KH, Pruden A (2006) Effect of River Landscape on the sediment concentrations of antibiotics and corresponding antibiotic resistance genes (ARG). Water Res 40:24272435. https://doi.org/10.1016/j.watres.2006.04.017

Qiao M, Ying GG, Singer AC, Zhu YG (2018) Review of antibiotic resistance in China and its environment. Environ Int 110:160-172. https://doi.org/10.1016/j.envint.2017.10.016

Sarmah AK, Meyer MT, Boxall ABA (2006) A global perspective on the use, sales, exposure pathways, occurrence, fate and effects of veterinary antibiotics (VAs) in the environment. Chemosphere 65:725-759. https://doi.org/10.1016/j.chemosphere.2006.03.026

Shaw JH, Clewell DB (1985) Complete nucleotide sequence of macrolide-lincosamide-streptogramin B-resistance transposon Tn917 in Streptococcus faecalis. J Bacteriol 164:782-796

Stalder T, Barraud O, Jove T, Casellas M, Gaschet M, Dagot C, Ploy MC (2014) Quantitative and qualitative impact of hospital effluent on dissemination of the integron pool. ISME J 8:768-777. https:// doi.org/10.1038/ismej.2013.189

Stuart L, Marshall B
Suzuki MT, Taylor LT (2000) Quantitative analysis of small-subunit rRNA genes in mixed microbial populations via $5 \mathrm{~J}$ - nuclease assays downloaded from https://aem.asm.org/ on November 26, 2014 by SERIALS CONTROL Lane Medical Library. 66:46054614. doi: 10.1128/AEM.66.11.4605-4614.2000

Thomas CM, Nielsen KM (2005) Mechanisms of, and barriers to, horizontal gene transfer between bacteria. Nat. Rev. Microbiol. 3:711

Tian Z, Zhang Y, Yu B, Yang M (2016) Changes of resistome, mobilome and potential hosts of antibiotic resistance genes during the transformation of anaerobic digestion from mesophilic to thermophilic. Water Res 98:261-269. https://doi.org/10.1016/j. watres.2016.04.031

Tran JH, Jacoby GA (2002) Mechanism of plasmid-mediated quinolone resistance. Proc Natl Acad Sci. https://doi.org/10.1073/ pnas.082092899

Trobos M, Jakobsen L, Olsen KEP et al (2008) Prevalence of sulphonamide resistance and class 1 integron genes in Escherichia coli isolates obtained from broilers, broiler meat, healthy humans and urinary infections in Denmark. Int. J. Antimicrob. Agents 32:367-369

Verlicchi P, Galletti A, Masotti L (2010) Management of hospital wastewaters: the case of the effluent of a large hospital situated in a small town. Water Sci Technol. https://doi.org/10.2166/ wst. 2010.138

Vikesland PJ, Pruden A, Alvarez PJJ et al (2017) Toward a comprehensive strategy to mitigate dissemination of environmental sources of antibiotic resistance. Environ Sci Technol 51:13061-13069. https://doi.org/10.1021/acs.est.7b03623

Wang Q, Wang P, Yang Q (2018) Occurrence and diversity of antibiotic resistance in untreated hospital wastewater. Sci Total Environ 621(B2):(B2):990-999-999. https://doi.org/10.1016/j.scito tenv.2017.10.128

Wen Q, Yang L, Duan R, Chen Z (2016) Monitoring and evaluation of antibiotic resistance genes in four municipal wastewater treatment plants in Harbin, Northeast China. Environ Pollut 212:34-40. https://doi.org/10.1016/j.envpol.2016.01.043 